\title{
Macroeconomic uncertainty and cost stickiness
}

\author{
Ziyang $\mathrm{Li}^{1, \mathrm{a}}$, Xi Cheng ${ }^{2, \mathrm{~b}}$, Mengwei Zhang ${ }^{3, \mathrm{c}}$, Xian Wen ${ }^{4, \mathrm{~d}}$ \\ ${ }^{1}$ Business School of Sichuan University, No.24 South Section 1, Yihuan Road, Chengdu, China \\ ${ }^{2}$ Business School of Sichuan University, No.24 South Section 1, Yihuan Road, Chengdu, China \\ ${ }^{3}$ Business School of Sichuan University, No.24 South Section 1, Yihuan Road, Chengdu, China \\ ${ }^{4}$ Business School of Sichuan University, No.24 South Section 1, Yihuan Road, Chengdu, China
}

\begin{abstract}
Cost management is the core issue related to the development of enterprises, and studying enterprise cost behavior will contribute to optimizing enterprise decisions. However, an enterprise is not an independent organization. Instead, it exists and is affected by the macroeconomic environment. So it is conducive for company to apply macroenvironment information to cost management behaviors. This paper studies the cost stickiness based on the perspective of macroeconomic uncertainty, and takes "adjustment cost" and "agency problems" as the internal logic to integrate into the existing interpretation framework of cost stickiness. We analyze SG\&A costs for Chinese listed firms over the period 2013 - 2019 after controlling for known economic determinants. The results show a positive relation between the macroeconomic uncertainty and the degree of cost asymmetry. In particular, the macroeconomic uncertainty makes the cost stickiness of human resource cost weaken.
\end{abstract}

\section{INTRODUCTION}

With increasingly violent competition of market, it is of paramount importance to operate at a lower cost than competitors for companies that seek to be competitive. Therefore, cost behaviors are always factors standing out in firms that need to be attached importance to. Since Anderson et al. (2003) pioneered proposing the concept of "cost stickiness", cost stickiness has attracted much attention from academia 8. Cost stickiness refers to the phenomena that costs increase more when activity rises than they decrease when activity falls. Currently, scholars' research on what can affect cost stickiness is mainly focused on microcosmic factors such as corporate internal governance, corporate cost structure characteristics and so forth 214, while little attention has been paid to the macroeconomic environment outside the enterprise. However, the macroeconomic environment is an important factor affecting its decision-making. Therefore, clarifying the mechanism of action about how macroeconomic uncertainty influences corporate cost stickiness will be conducive to prompt companies to make effective cost management decisions and improve the efficiency of enterprise resource allocation.

Based on this, this paper selects the data of listed companies in China over the period 2013-2019 as a sample and uses the conditional variance of the quarterly GDP growth rate calculated by GARCH $(1,1)$ as an indicator for measuring macroeconomic uncertainty to explore the possible impact of macroeconomic uncertainty on the cost stickiness. The empirical results show that the uncertainty of the macroeconomic environment makes the cost stickiness of the enterprise more significant due to agency problem; In addition, we find that macroeconomic uncertainty mitigates cost asymmetry mainly through reducing the adjustment cost like search costs and contracting costs required to recruit new employees, and the stickiness of human resource costs will be significantly reduced.

Our study makes the following contributions. First, we inject fresh blood into the study of corporate cost stickiness. Prior research has mostly examined the impact on corporate cost stickiness from microcosmic perspective, but this paper analyzes the cost stickiness behavior based on the perspective of macroeconomic uncertainty, taking "adjustment costs" and "agency problems" as the internal logic to enrich the interpretation framework of cost stickiness, which helps to better understand the cost management behavior of enterprises.

Second, our study adds to a stream of empirical studies about the impact of macroeconomic uncertainty on corporate cost behavior. Although existing literature examines the significant impact of macroeconomic uncertainty on many economic activities in the fields of industrial output, corporate investment and financing and household consumption behaviors, little evidence exists on its effect on corporate cost decision. This article enriches this area and finds that macroeconomic uncertainty will increase the cost stickiness of enterprises, and also it will reduce the stickiness of human resource costs to a certain extent.

Third, we provide theoretical reminders for enterprises in the environment of macroeconomic uncertainty. An enterprise is not an independent organization. Instead, it exists and is affected by the macroeconomic environment. 
This theory reminds managers that when making cost decisions, they must consider the overall impact of the macroeconomic environment on resource adjustments and changes in corporate governance efficiency.

\section{LITERATURE REVIEW}

\subsection{Macroeconomic uncertainty}

Different from the uncertainty of economic policies, macroeconomic uncertainty refers to the unpredictable part of future economic development caused by shocks from the real economy level such as enterprises and industries 18. Macroeconomic uncertainty has an important impact on economic activities in many areas. In the area of industrial output, there were some studies showing that U.S. uncertainty shocks lead a significant decline in foreign economies' output 11. In terms of investment and financing, related research shows that uncertainty will affect the process of investment and decision made by stock market investors 10; There is also some literature that studies the role of economic uncertainty in the cross-sectional pricing of individual stocks and equity portfolios19. In addition, households' consumption behavior also responds to the economic uncertainty in a similar way, by reducing consumption of durable goods. We can draw a conclusion from above that economic uncertainty is an important indicator of economic parameters and is closely related to a large number of economic activities.

\subsection{Cost stickiness}

Cost stickiness refers to the asymmetry of corporate costs when activity volume increases or decreases. Anderson, Banker, and Janakiraman (2003) pioneered borrowing the concept of "price stickiness" in economics (Hamermesh and Pfann, 1996) and proposed the concept of "cost stickiness" used to define this phenomenon for the first time. What is more, they took the sales and management expenses (SG \& A) of the US public company as the research object, and verified the existence of cost stickiness in the US public company 85. Based on the research by Anderson, Banker, and Janakiraman (2003), related research on cost stickiness has attracted the attention of many scholars at home and abroad, and has produced many related academic results 8 .

In the related research on the cause of cost stickiness, Banker et al. (2013) summed up the causes of cost stickiness into three aspects: adjustment costs, optimistic expectations of managers and agency problems 11 (1)Adjustment costs: Scholars such as Anderson, Banker and Janakiraman (2003), Subramaniam and Weidenmier (2003), Banker and Chen (2013) support this perspective from aspects of resource types, activity volume changes, and labor market characteristics 915 . In addition, Banker et al. (2013) investigated the impact of employment protection laws in OECD countries on asymmetric cost behavior. (2) Optimistic expectations of managers. Research by Anderson, Banker, and Janakiraman (2003) found that when a company's sales decline for two consecutive years, managers' optimistic expectations of the company's future sales will weaken, thereby weakening the cost stickiness of the company8. While during the growth period, managers' optimistic expectations for the future will increase, thereby strengthening the cost stickiness of enterprises. Kama and Weiss (2010) and Banker et al. (2014) also found results consistent with the above studies616. In addition, Balakrishnan et al. (2014) and Banker et al. (2017) proposed that a high level of debt constraints hinders managerial decision making on reducing optional resources in proportion to decreased economic activity 1413. (3) Agency problems. Due to the agency problem between managers and shareholders, managers are always self-interested in making adjustments to various committed resources. These behaviors make cost behavior and the optimal resources of the enterprise do not agree, which causes cost stickiness. Scholars such as Calleja et al. (2006), Dierynck, and Renders (2009) and Chen et al(2012)support the agency problem from the aspects of corporate governance model and corporate governance structure 71 .

\section{TheORETICAL ANALYSIS AND Hypothesis}

The agency problem view argues that managers may intentionally delay or abandon the decision to reduce binding resources in order to obtain personal benefits indirectly, although reducing these resources is beneficial to the business. It is true that companies can consider regulating managers' behaviors by stipulating behavioral contracts to make their behaviors consistent with corporate goals. However, if these regulations are just general behavioral rules without fully taking into account the various possible changes in the macroenvironment, it will restrict business activities and make operators lose the adaptability to an unforeseen future. Therefore, in order to stipulate the manager's behavior through a behavior contract, both parties to the contract must have sufficient information to foresee various possible changes in the environment. However, collecting, transmitting, and organizing information all requires fees. The more difficult it is to get enough information, the higher the cost of information will be. In the case of macroeconomic uncertainty, the required information costs are higher, and even some information is not available at all, which means the information cost tends to infinity. Therefore, it is also less likely for companies to make detailed regulations on the behavior of managers, thereby leaving somewhat free decision-making space for managers, and provides possibility for manager's opportunistic behavior Further, prior research suggests that uncertainty accentuates information asymmetry, so it is more difficult to supervise managers and reduce the likelihood that managers' self-interest behaviors can be discovered 4 . Therefore, when the macroeconomic environment is facing greater uncertainty, the agency problem between managers and shareholders may be exacerbated, resulting in higher cost stickiness. Based on the above analysis, this article proposes the first hypothesis: 
H1: Macroeconomic uncertainty will increase the cost stickiness of enterprises.

Cost stickiness can also stem from adjustment cost. For human resources, the adjustment costs borne by the company include not only severance payments paid for firing employees, but also the search costs, contract costs, and training costs required to recruit new employees. Because of macroeconomic uncertainty, the search costs and contracting costs required to recruit new employees will be significantly reduced. Some literature suggests that macroeconomic uncertainty will have a bad impact on employment in the labor market 17 . With the generally depressing employment environment, on the one hand, the number of unemployed labors is large, so the company's search costs for recruiting new employees are reduced, which reduces cost stickiness; on the other hand, the negotiation ability to bargaining a higher salary for labors themselves is likely to be weaker, which results in the decrease of contracting cost, and thus making cost stickiness weaker, too. Based on the above analysis, a second hypothesis is proposed:

$\mathrm{H}$ 2: Macroeconomic uncertainty will weaken the stickiness of human resources costs in enterprises.

\section{Sample selection and Methodology}

\subsection{Measuring macroeconomic uncertainty}

In order to consider the effect of macroeconomic uncertainty on cost stickiness, we need first quantify macroeconomic uncertainty. A common measure is a generalized autoregressive conditional heteroscedasticity (GARCH) model. The formula is as follows:

$$
\begin{gathered}
m_{t}=\alpha_{0}+\alpha_{i} \sum_{i=1}^{n} m_{t-i}+e_{t} . \\
h_{t}=\gamma_{0}+\gamma_{1} e_{t-1}^{2}+\gamma_{2} h_{t-1} .
\end{gathered}
$$

Among them, $\mathrm{m}_{\mathrm{t}}$ is the logarithmic first order differential of macroeconomic variables; $e_{t}$ is the stochastic error, and $h_{t}$ is the conditional variance of the error obtained through GARCH estimation. First, we perform regression on the logarithmic difference of China's quarterly GDP, and then use the LM test to determine the ARCH (1) effect. The test result shows $\mathrm{PROB}>\mathrm{CHI} 2=0.0038<0.05$. Therefore, we can estimate the coefficients of ARCH (1) by specifying the ARCH (1) model. Through the regression of ARCH (1) and GARCH (1), we estimate that the coefficient of ARCH (1) is 0.55 and the coefficient of GARCH (1) is -0.35 , so we can stipulate GARCH $(1,1)$ model. After forecasting, we can get the measurement of macroeconomic uncertainty.

\subsection{Sample selection and the source of data}

We collect and sort the data of listed companies from the first quarter of 2013 to the fourth quarter of 2019 as a research sample. The data of listed companies is derived from the CSMAR database and duplicate and error values are manually removed. We remove ST, PT, and financial companies; and the observations that the company's missing employee compensation and sales income in the current year and the previous year, and that the company's current employee compensation is greater than the sales income. The indicator of measuring uncertainty is calculated as above. In the end, this paper obtained annual observations of 58513 companies.

\subsection{Model design and variable definition}

This paper uses the cost stickiness model of Anderson et al. (2003) to test the existence of cost stickiness first.

$$
\Delta \mathrm{SG} \& \mathrm{~A}=\beta_{0}+\beta_{1} \Delta \operatorname{Rev}_{(\mathrm{i}, \mathrm{t})}+\beta_{2} \mathrm{D} \times \Delta \operatorname{Rev}_{(\mathrm{i}, \mathrm{t})}+\varepsilon_{(\mathrm{i}, \mathrm{t})} .
$$

In order to verify $\mathrm{H} 1$, this article introduces the economic uncertainty index $\operatorname{Var} \times \mathrm{D} \times \Delta \operatorname{Rev}_{(\mathrm{i}, \mathrm{t})}$ in the basic model. And this paper draws on the research ideas in controlling asset intensity and other factors to control adjustment costs and agency costs. In addition, we use the dummy variable (SP) to control the interference of the management intention of surplus on the results. If $\beta 3$ in model (2) is negative, it means that the cost stickiness is enhanced when the economic uncertainty is strong. The research model is as follows:

$\Delta \mathrm{SG} \& \mathrm{~A}=\beta_{0}+\beta_{1} \Delta \operatorname{Rev}_{(\mathrm{i}, \mathrm{t})}+\beta_{2} \mathrm{D} \times \Delta \operatorname{Rev}_{(\mathrm{i}, \mathrm{t})}+\beta_{3} \times \operatorname{Var} \times \mathrm{D} \times \Delta \mathrm{Re}$ $\mathrm{v}_{(\mathrm{i}, \mathrm{t})}+\beta_{4} \times \mathrm{AI}+\beta_{5} \times \mathrm{EI}+\beta_{6} \times \mathrm{FI}+\beta_{7} \times \mathrm{FCF}+\beta_{8} \times \mathrm{SP}+\beta_{9} \times \mathrm{GDP}+\beta_{10}$

$$
\times \text { Lev }+\beta_{11} \times \text { Suc_Dec }+\varepsilon_{(i, t)} \text {. }
$$

Substituting $\triangle \mathrm{TP}$ into the above model to verify Hypothesis 2. The model is as (3).

(1) $\Delta \mathrm{TP}=\beta_{0}+\beta_{1} \Delta \operatorname{Rev}_{(\mathrm{i}, \mathrm{t})}+\beta_{2} \mathrm{D} \times \Delta \operatorname{Rev}_{(\mathrm{i}, \mathrm{t})}+\beta_{3} \times \operatorname{Var} \times \mathrm{D} \times \Delta \mathrm{Rev}_{(\mathrm{i}, \mathrm{t})}{ }^{+}$ $\beta_{4} \times \mathrm{AI}+\beta_{5} \times \mathrm{EI}+\beta_{6} \times \mathrm{FI}+\beta_{7} \times \mathrm{FCF}+\beta_{8} \times \mathrm{SP}+\beta_{9} \times \mathrm{GDP}+\beta_{10} \times \mathrm{Lev}$

$$
+\beta_{11} \times \text { Suc_Dec }+\varepsilon_{(i, t)} \text {. }
$$

\begin{tabular}{|c|c|}
\hline Variable & Variable Calculation \\
\hline SG\&A & Selling expenses plus Administrative expense \\
\hline Rev & Prime operating revenue \\
\hline$\triangle \mathrm{SG} \& \mathrm{~A}$ & 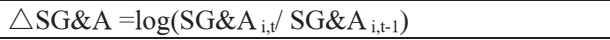 \\
\hline$\triangle \operatorname{Rev}$ & $\triangle \operatorname{Rev}=\log \left(\operatorname{Rev}_{\mathrm{i}, \mathrm{t}} / \operatorname{Rev}_{\mathrm{i}, \mathrm{t}-1}\right)$ \\
\hline$\triangle \mathrm{TP}$ & $\triangle \mathrm{TP}=\log \left(\right.$ Employee salary $_{\mathrm{i}, \mathrm{t}} /$ Employee salary $\left._{\mathrm{i}, \mathrm{t}-1}\right)$ \\
\hline $\mathrm{D}$ & $\begin{array}{l}\text { Revenue this year is lower than the prior year's } \\
\text { income, } \mathrm{D}=1 \text {, otherwise } 0 \text {. }\end{array}$ \\
\hline Var & $\begin{array}{l}\text { Use GARCH }(1,1) \text { to get the conditional variance of } \\
\text { quarterly GDP, then take the mean. }\end{array}$ \\
\hline $\mathrm{AI}$ & $\mathrm{AI}=\log ($ Asset/Revenue $)$ \\
\hline EI & $\mathrm{EI}=\log ($ Number of employees/Revenue $)$ \\
\hline FI & $\mathrm{FI}=\log ($ Fixed asset/Revenue $)$ \\
\hline FCF & $\mathrm{FCF}=$ Free cash flow/Asset \\
\hline SP & $0<\mathrm{ROA}<0.01, \mathrm{SP}=1$. Otherwise 0 . \\
\hline GDP & $\mathrm{GDP}=\ln \left(\mathrm{GDP}_{\mathrm{i}, \mathrm{t}}\right)$ \\
\hline Lev & Lev $=$ Debt/Asset \\
\hline Suc_Dec & $\begin{array}{l}\text { Dummy Variables. Revenue decreases for two } \\
\text { consecutive years, Suc_Dec }=1 \text {, otherwise } 0 .\end{array}$ \\
\hline
\end{tabular}

(2)

Variable symbols, definitions and calculations in the above model are shown in Table I.

TABLE I. VARIABLE DESCRIPTION 


\section{EMPIRICAL RESULTS}

\subsection{Descriptive statistics of main variables}

Table II lists the descriptive statistics of the main variables in this paper. Among them, the mean (median) of $\triangle \mathrm{SG} \& \mathrm{~A}$ is $-0.04(-0.01)$, indicating that SG\&A of the sample company is increasing during the investigation phase. Among the control variables, the mean of AI, EI, FI are all similar to the current literature; The mean of Suc_ Dec is 0.49 , indicating that $49 \%$ of the sample companies have experienced a decline in revenue for two consecutive years.

TABLE II. DESCRIPTIVE STATISTIC

\begin{tabular}{|l|c|l|l|l|l|l|}
\hline Variable & \multicolumn{1}{c|}{$\mathbf{N}$} & \multicolumn{1}{c|}{ Mean } & \multicolumn{1}{c|}{ Sd } & Median & \multicolumn{1}{|c|}{ Min } & \multicolumn{1}{c|}{ Max } \\
\hline SG\&A & 58513 & $2.2 \mathrm{e}+08$ & $1.2 \mathrm{e}+09$ & $5.1 \mathrm{e}+07$ & $\begin{array}{l}6.2 \mathrm{e}+07 \\
1.2 \mathrm{e}+11\end{array}$ \\
\hline Rev & 58513 & $2.5 \mathrm{e}+09$ & $1.9 \mathrm{e}+10$ & $4.0 \mathrm{e}+08$ & 660.00 & $1.7 \mathrm{e}+12$ \\
\hline $\begin{array}{l}\triangle \\
\text { SG\&A }\end{array}$ & 58513 & -0.04 & 0.53 & -0.01 & -8.37 & 7.76 \\
\hline$\triangle$ Rev & 58513 & -0.02 & 0.64 & 0.01 & -11.15 & 10.99 \\
\hline$\triangle \mathrm{TP}$ & 38138 & 0.56 & 1.88 & 0.57 & -10.29 & 19.01 \\
\hline $\mathrm{D}$ & 58513 & 0.49 & 0.50 & 0.00 & 0.00 & 1.00 \\
\hline $\begin{array}{l}\text { D* } \\
\text { Rev }\end{array}$ & 58513 & -0.20 & 0.41 & 0.00 & -11.15 & 0.00 \\
\hline Var & 58513 & 0.02 & 0.01 & 0.02 & 0.00 & 0.05 \\
\hline $\begin{array}{l}\text { Var*D* } \\
\triangle \text { Rev }\end{array}$ & 58513 & -0.00 & 0.01 & 0.00 & -0.22 & 0.00 \\
\hline AI & 58513 & 0.49 & 2.06 & 0.88 & -9.82 & 13.74 \\
\hline EI & 58513 & -13.58 & 1.08 & -13.52 & -20.11 & -2.51 \\
\hline FI & 58513 & -1.28 & 2.35 & -0.86 & -14.38 & 11.57 \\
\hline FCF & 58513 & 0.83 & 90.93 & 0.01 & - & 20342.48 \\
\hline SP & 58513 & 0.39 & 0.49 & 0.00 & 0.00 & 1.00 \\
\hline GDP & 58513 & 11.68 & 0.55 & 11.37 & 11.84 & 12.10 \\
\hline Lev & 58513 & 0.56 & 13.71 & 0.56 & -510.38 & 2038.52 \\
\hline Suc_Dec & 58513 & 0.49 & 0.50 & 0.00 & 0.00 & 1.00 \\
\hline
\end{tabular}

\subsection{Results of Regressing}

Table III reports the regression results of models (1) and (2), in which control variables are progressively introduced into regression to ensure the accuracy of the results. The coefficient of the cross term $D^{*} \triangle \operatorname{Rev}$ in Reg I and Reg II is significantly negative at the level of $1 \%(-$ $0.184, \mathrm{t}=-20.99 ;-0.299, \mathrm{t}=-34.69$ ), which proves that there is a significant cost stickiness phenomenon in Chinese enterprises. Reg III introduced the cross-term Var* $D^{*} \triangle$ Rev to measure the relationship between economic uncertainty and cost stickiness. Its coefficient is significantly negative at the level of $1 \%(-2.379, \mathrm{t}=-2.19)$. After adding the control variable in Reg IV, the coefficient of Var* $\mathrm{D} * \triangle \operatorname{Rev}$ is still significantly negative $(-4.218, t=-4.04)$. The regression results show a positive relationship between cost stickiness and economic uncertainty, which supports $\mathrm{H} 1$.

TABLE III. ECONOMIC UNCERTAINTY AND CORPORATE COST STICKINESS

\begin{tabular}{|l|l|l|l|l|l|}
\hline Variable & & \multicolumn{1}{c|}{ Reg I } & \multicolumn{1}{c|}{ Reg II } & \multicolumn{1}{c|}{ Reg III } & \multicolumn{1}{c|}{ Reg IV } \\
\hline \multirow{2}{*}{ cons } & \multirow{2}{*}{$\beta_{0}$} & $\begin{array}{l}-0.064 * * * \\
(-25.58)\end{array}$ & $\begin{array}{l}-0.595 * * * \\
(-11.44)\end{array}$ & $\begin{array}{l}-0.063 * * * \\
(-25.45)\end{array}$ & $\begin{array}{l}-0.608 * * * \\
(-11.67)\end{array}$ \\
\hline
\end{tabular}

\begin{tabular}{|c|c|c|c|c|c|}
\hline$\triangle \operatorname{Rev}$ & $\beta_{1}$ & \begin{tabular}{|l}
$0.489 * * *$ \\
$(94.55)$ \\
\end{tabular} & \begin{tabular}{|l}
$0.455^{* * *}$ \\
$(89.64)$ \\
\end{tabular} & $\begin{array}{l}0.489^{* * *} \\
(94.49)\end{array}$ & \begin{tabular}{|l}
$0.454 * * * *$ \\
$(89.49)$ \\
\end{tabular} \\
\hline $\mathrm{D}^{*} \triangle \operatorname{Rev}$ & $\beta_{2}$ & $\begin{array}{l}-0.184^{* * * * *} \\
(-20.99)\end{array}$ & $\begin{array}{l}-0.299 * * * * \\
(-34.69)\end{array}$ & $\begin{array}{l}-0.139^{* * *} \\
(-6.32)\end{array}$ & {$\left[\begin{array}{l}-0.221^{* * *} \\
(-10.39)\end{array}\right.$} \\
\hline $\begin{array}{l}\operatorname{lar}{ }^{*} D^{*} \triangle \\
\text { Rev }\end{array}$ & $\beta_{3}$ & & & $\begin{array}{l}-2.379 * * \\
(-2.19)\end{array}$ & $\begin{array}{l}-4.218^{* * *} \\
(-4.04)\end{array}$ \\
\hline AI & $\beta_{4}$ & & $\begin{array}{l}-0.059^{* * * *} \\
(-39.15)\end{array}$ & & $\mid \begin{array}{l}-0.0599^{* * *} \\
(-39.16)\end{array}$ \\
\hline EI & $\beta_{5}$ & & $\begin{array}{l}0.004 * * * \\
(1.26)\end{array}$ & & $\begin{array}{l}0.004 * * * \\
(1.16)\end{array}$ \\
\hline FI & $\beta_{6}$ & & $\begin{array}{l}-0.014 \\
(-10.44) \\
\end{array}$ & & $\begin{array}{l}-0.014 \\
(-10.38)\end{array}$ \\
\hline FCF & $\beta_{7}$ & & $\begin{array}{l}-0.000^{*} \\
(-1.75)\end{array}$ & & $\begin{array}{l}-0.000^{*} \\
(-1.74)\end{array}$ \\
\hline SP & $\beta_{8}$ & & $\begin{array}{l}-0.011 * * \\
(-2.55)\end{array}$ & & $\mid \begin{array}{l}-0.011^{* *} \\
(-2.54)\end{array}$ \\
\hline GDP & $\beta_{9}$ & & $\begin{array}{l}0.050^{* * * *} \\
(11.77)\end{array}$ & & $\begin{array}{l}0.051^{* * * *} \\
(11.96)\end{array}$ \\
\hline Lev & $\beta_{10}$ & & $\begin{array}{l}0.000^{* *} \\
(-1.75)\end{array}$ & & $\begin{array}{l}-0.000^{*} \\
(-1.74)\end{array}$ \\
\hline Suc_Dec & $\beta_{11}$ & & $\begin{array}{l}-0.018^{* * * *} \\
(-4.35)\end{array}$ & & $\begin{array}{l}-0.019^{* * *} \\
(-4.60)\end{array}$ \\
\hline Year & & yes & yes & yes & yes \\
\hline Firm & & yes & & & yes \\
\hline AdjR2 & & 0.194 & 0.263 & 0.194 & 0.263 \\
\hline $\mathrm{F}$ & & 8716 & 2423 & 5813 & 2205 \\
\hline $\mathrm{N}$ & & 58513 & 58513 & 58513 & 58513 \\
\hline
\end{tabular}

Regression in Table IV is performed to explore the relationship between economic uncertainty and the stickiness of human resource costs. The coefficient of the cross term $D^{*} \triangle \operatorname{Rev}$ in Reg I and Reg II is significantly negative at the level of $1 \%(-0.536, t=-38.50 ;-0.522, t=-$ 36.49), which proves that there is a significant sticky phenomenon in the human resource costs of Chinese enterprises. We predict a negative relationship between economic uncertainty and the stickiness of human resource costs, after controlling for known economic determinants. Therefore, we expect $\beta_{3}$ in Reg IV to be positive. Reg IV shows that its coefficient is significantly positive (7.923, $\mathrm{t}=4.62$ ), thus proving $\mathrm{H} 2$.

TABLE IV. ECONOMIC UNCERTAINTY AND CORPORATE LABOR COST STICKINESS

\begin{tabular}{|c|c|c|c|c|c|}
\hline Variable & & Reg I & Reg II & Reg III & Reg IV \\
\hline Cons & $\beta_{0}$ & $\begin{array}{l}1.107 * * * \\
(281.36)\end{array}$ & $\begin{array}{l}0.752 * * * \\
(8.35)\end{array}$ & $\begin{array}{l}1.106 * * * \\
(280.91)\end{array}$ & $\begin{array}{l}0.781^{\text {**** }} \\
(8.66)\end{array}$ \\
\hline$\triangle \operatorname{Rev}$ & $\beta_{1}$ & $\begin{array}{l}0.473 * * * \\
(57.70)\end{array}$ & $\begin{array}{l}0.474 * * * \\
(56.45)\end{array}$ & $\begin{array}{l}0.474 * * * \\
(57.78)\end{array}$ & $\begin{array}{l}0.476^{* * * *} \\
(56.57)\end{array}$ \\
\hline $\begin{array}{l}\mathrm{D}^{*} \quad \triangle \\
\operatorname{Rev}\end{array}$ & $\beta_{2}$ & $\begin{array}{l}- \\
0.536 * * * \\
(-38.50)\end{array}$ & $\begin{array}{l}- \\
0.522 * * * \\
(-36.49)\end{array}$ & $\begin{array}{l}- \\
0.667 * * * \\
(-19.21)\end{array}$ & $\begin{array}{l}- \\
0.669 * * * \\
(-19.17)\end{array}$ \\
\hline $\begin{array}{l}\text { Var* D* } \\
\triangle \operatorname{Rev}\end{array}$ & $\beta_{3}$ & & & $\begin{array}{l}7.034 * * * \\
(4.11)\end{array}$ & $\begin{array}{l}7.923 * * * \\
(4.62)\end{array}$ \\
\hline AI & $\beta_{4}$ & & $\begin{array}{l}- \\
0.010 * * * \\
(-3.84)\end{array}$ & & $\begin{array}{l}- \\
0.010 * * * \\
(-3.83)\end{array}$ \\
\hline EI & $\beta_{5}$ & & $\begin{array}{l}- \\
0.035 * * * \\
(-6.80)\end{array}$ & & $\begin{array}{l}- \\
0.034 * * * \\
(-6.68)\end{array}$ \\
\hline FI & $\beta_{6}$ & & $\begin{array}{l}0.021 * * * \\
(9.27)\end{array}$ & & $\begin{array}{l}0.021 \text { *** } \\
(9.19)\end{array}$ \\
\hline FCF & $\beta_{7}$ & & $\begin{array}{l}0.000 \\
(1.09)\end{array}$ & & $\begin{array}{l}0.000 \\
(1.08)\end{array}$ \\
\hline SP & $\beta_{8}$ & & $\begin{array}{l}-0.005 \\
(-0.71)\end{array}$ & & $\begin{array}{l}-0.005 \\
(-0.75)\end{array}$ \\
\hline GDP & $\beta_{9}$ & & $\begin{array}{l}-0.010 \\
(-1.36)\end{array}$ & & $\begin{array}{l}-0.012 \\
(-1.63)\end{array}$ \\
\hline Lev & $\beta_{10}$ & & $\begin{array}{l}-0.000 \\
(-0.51)\end{array}$ & & $\begin{array}{l}-0.000 \\
(-0.50)\end{array}$ \\
\hline
\end{tabular}




\begin{tabular}{|l|l|l|l|l|l|}
\hline Suc_Dec & $\beta_{11}$ & & $\begin{array}{l}0.067 * * * \\
(9.73)\end{array}$ & $\begin{array}{l}0.070^{* * *} \\
(10.01)\end{array}$ \\
\hline Year & & yes & yes & yes & yes \\
\hline Firm & & yes & yes & yes & yes \\
\hline AdjR2 & & 0.003 & 0.008 & 0.004 & 0.008 \\
\hline F & & 1751.246 & 378.566 & 1173.483 & 346.223 \\
\hline N & & 57079 & 57079 & 57079 & 57079 \\
\hline
\end{tabular}

\section{ConCLUSION}

This paper analyzes the cost stickiness behavior based on the perspective of macroeconomic uncertainty, taking "adjustment costs" and "agency problems" as the internal logic. We use the data of Chinese listed companies from 2013 to 2019 as a sample to explore the possible impact of macroeconomic uncertainty on the cost stickiness and its mechanism. The empirical results show that macroeconomic uncertainty makes it more impossible for companies to make detailed regulations on the behavior of managers, and provides more space for opportunistic behavior .The greater degree of information asymmetry also reduces the possibility that managers' self-interest behaviors can be discovered, making the cost stickiness more significant; In addition, we find that macroeconomic uncertainty mitigates cost asymmetry mainly through reducing the adjustment cost like search costs and contracting costs required to recruit new employees, and the stickiness of human resource costs will be significantly reduced.

The results of our study should be interpreted with caveats: Nowadays, studying cost behavior plays an increasingly central role in optimizing corporate decisions and improving economic benefits. However, enterprises exist and are affected by the external macroenvironment, so companies must consider the overall impact of macroenvironment on resource adjustment and corporate development opportunities, especially in the case of high microeconomic uncertainty. In addition, it is wise for the government to take more prudent fiscal policies measures in the future as well as strengthening international cooperation and easing trade frictions to alleviate macroeconomic uncertainty and promote the global economy increase.

\section{ACKNOWLEDGMENT}

We thank for the foundation of National Natural Science Foundation of China (71902128). All the authors share the same contribution.

\section{REFERENCES}

1. B. Dierynck, W. R. Landsman, and A. Renders, "Do Managerial Incentives Drive Cost Behavior? Evidence about the Role of the Zero Earnings Benchmark for Labor Cost Behavior in Belgian Private Firms," Social Science Electronic Publishing, vol. 87, no. 4, pp. 1219-1246, 2009.

2. C. X. Chen, H. LU, and T. SOUGIANNIS, "The Agency Problem, Corporate Governance, and the Asymmetrical Behavior of Selling, General, and
Administrative Costs," Contemporary Accounting Research, vol. 29, no. 1, pp. 252-282.

3. E. Noreen and N. Soderstrom, "The Accuracy of Proportional Cost Models: Evidence from Hospital Service Departments," Review of Accounting Studies, vol. 2, no. 1, pp. 89-114, 1997.

4. G. A. Akerlof, “The Market for 'Lemons': Quality Uncertainty and the Market Mechanism," Quarterly Journal of Economics, vol. 84, 1970.

5. H. G. A. Pfann, "Turnover and the Dynamics of Labour Demand," Economica, vol. 63, no. 251, pp. 359-367.

6. I. KAMA and D. WEISS, "Do Earnings Targets and Managerial Incentives Affect Sticky Costs?,' Journal of Accounting Research, vol. 51, no. 1, pp. 201-224.

7. K. Calleja, M. Steliaros, and D. C. Thomas, "A note on cost stickiness: Some international comparisons," vol. 17, no. 2, pp. 0-140.

8. M. C. Anderson, R. D. Banker, and S. N. Janakiraman, "Are Selling, General, and Administrative Costs \"Stickyl"?," Journal of Accounting Research, vol. 41, no. 1, pp. 47-63.

9. M. L. Weidenmier and C. Subramaniam, "Additional Evidence on the Sticky Behavior of Costs," Social Science Electronic Publishing, 2003.

10. N. Barberis, H. Ming, and T. Santos, "Prospect Theory and Asset Prices," Nber Working Papers, vol. 116, no. 1, pp. 1-53, 1999.

11. P. M.Jones, and E.Olson, " The international effects of US uncertainty,"J. International Journal of Finance and Economics, vol.20,no.3, pp.242$252,2015$.

12. R. Balakrishnan, E. Labro, and N. S. Soderstrom, "Cost Structure and Sticky Costs," Journal of Management Accounting Research, no. forthcoming, 2014.

13. R. Banker, D. Byzalov, S. Fang, and Y. Liang, "Cost Management Research," Social Science Electronic Publishing, 2018.

14. R.Balakrishnan, E. Labro, and N. S. Soderstrom, "Cost Structure and Sticky Costs," Working paper (The University of Iowa, Iowa City,IA), 2011.

15. R. D. Banker, D. Byzalov, and L. (Tony) Chen, "Employment protection legislation, adjustment costs and cross-country differences in cost behavior," Journal of Accounting \& Economics, vol. 55, no. 1, pp. 111-127.

16. R.D. Banker, D. Byzalov, M. Ciftci, et al. "The Moderating Effect of Prior Sales Changes on Asymmetric Cost Behavior," J. Journal of Management Accounting Research, vol.26,no.2, 2014.

17. S. Leduc and Z. Liu, "Uncertainty shocks are aggregate demand shocks," vol. 82, pp. 20-35

18. S. R. Bakera, N. Bloomb, and S. J. Davisc, "Measuring Economic Policy Uncertainty," Social Science Electronic Publishing. 
19. T. G. Bali, S. J. Brown, and Y. Tang, "Is economic uncertainty priced in the cross-section of stock returns?," Journal of Financial Economics, vol. 126, no. 3, p. págs. $471-489,2017$ 